\title{
Colonization by mites of glacier-free areas in King George Island, Antarctica
}

\author{
Grzegorz Gryziak ${ }^{(1,2)}$ \\ (1)Polish Academy of Sciences, Centre for Ecological Research, ul. Konopnickiej 1, 05-092 Łomianki, Poland. E-mail: ggryziak@cbe-pan.pl \\ (2)Polish Academy of Sciences, Department of Antarctic Biology, Ustrzycka 10/12, 02-141 Warszawa, Poland.
}

\begin{abstract}
This work aimed to investigate the ratio of colonization by terrestrial mites on ice-free areas created by the ongoing climate-induced melting of Antarctic glaciers. Glacier retreat opens new ice-free areas for the colonization by vegetation and animals. The study was undertaken on the Antarctic Specially Protected Area no. 128 (West Coast of the Admiralty Bay, King George Island, South Shetlands Islands). Transects marked between the Ecology, Baranowski and Windy Glaciers, and a sea shore were used to collect soil samples. Oribatid mites were found only on near-shore areas, on patches of vegetation of more than 30 years of age. The colonization by mite communities is strongly determined by the presence of plants.
\end{abstract}

Index terms: oribatid mites, global change, glacier melting.

\section{Colonização por ácaros em áreas livres de geleiras na Ilha Rei George, Antárctica}

\begin{abstract}
Resumo - Este trabalho visou investigar a proporção de colonização, por ácaros terrestres, em áreas de terra seca criadas pelo contínuo derretimento das geleiras antárticas induzido pelas condições climáticas. O recuo das geleiras abre novas áreas livres de gelo para a colonização pela vegetação e por animais. O estudo foi conduzido na Área de Proteção Especial da Antártica número 128 (ASPA no 128, costa oeste da Baía do Almirantado, Ilha Rei George, Ilhas Shetland do Sul). Transectos marcados entre as geleiras Ecology, Baranowski e Windy e a costa marítima foram utilizados para coletar amostras de solo. Os ácaros oribatídeos foram encontrados somente em áreas próximas da costa em manchas de vegetação com mais de 30 anos de idade. A colonização das áreas de terra pelas comunidades de ácaros é fortemente determinada pela presença de plantas.
\end{abstract}

Termos para indexação: ácaros oribatídeos, mudança global, derretimento das geleiras.

\section{Introduction}

Consequences of global warming have gained much attention in scientific papers (Hogg et al., 1995; Hughes, 2000; Gates, 1993). It is believed that global warming is causing glacier recession. Glaciers are generally vulnerable to the presence of greenhouse gases in the atmosphere and can be considered indicators of climatic change (Oerlemans, 1986). A direct and plausible effect of glacier retreat is the opening of new ice-free areas for the colonization by terrestrial vegetation and animals, in which the colonization process can be observed from the beginning.

The Windy, Baranowski and Ecology Glaciers are part of the Warszawa Icefield. During the past decade, a rapid retreat of these valley-type tidewater glaciers has been observed. The Ecology Glacier retreat was described in detail by Birkenmajer (2002). It has been under continuous recession at least since 1956/1957, but the rate decreased in 1988/1989, amounting to $4-4.5 \mathrm{~m}$ per year. It rapidly accelerated in the past decade (1989-1999), reaching a rate of up to $30 \mathrm{~m}$ per year. The same situation is present at the Windy and Baranowski Glaciers.

South Shetlands Islands, with a total ice-free area of about $400 \mathrm{~km}^{2}$, have 28 species of mites (Acari): 13 Prostigmata, 12 oribatid mites (Acari: Oribatida), 2 Mesostigmata, 1 Astigmata (Pugh \& Convey, 2000). In comparison, organic layers of temperate forest have at least 100 species $\mathrm{m}^{-2}$ of oribatid mites (Niedbała, 1980). The species composition of terrestrial arthropods in maritime Antarctic conditions is correlated with latitude, but the uneven abundance, the distribution and the local high beta diversity probably reflect habitat fragmentation and population isolation (Caruso $\&$ Bargagli, 2007). Their distribution is limited to areas of high soil moisture or with access to water, such as streams or snow meltwater (Sinclair \& Sjursen, 2001), and are strongly related to the chlorophyll- $a$ content of 
the soil, but their communities do not depend upon input of ornithogenic carbon (Sinclair, 2001). Mites prefer habitats covered by vegetation to bare soil, and lichens to mosses (Hiruta \& Ohyama, 1995; Bokhorst et al., 2008). Lichens, which grow in sites enriched by nutrients derived from sea birds, have rapid colonization and growth rates (Smith, 1995).

Few papers (Hiruta \& Ohyama, 1995; Bölter et al., 1997) have been published on the abundance of mites in Antarctica and little is know regarding the rate of colonization of new habitats. The aim of this study was to investigate the rate and patterns of colonization by terrestrial mites on ice-free areas created by the melting of maritime Antarctic glaciers.

\section{Materials and Methods}

This research was conducted as part of the International Polar Year 2007-2008 project - ClicOPEN (Impact of climate-induced glacial melting on marine and terrestrial coastal communities on a gradient along the Western Antarctic Peninsula) -, during the $32^{\text {nd }}$ Polish Antarctic Expedition. Antarctic Specially Protected Area no. 128 $\left(62^{\circ} 11^{\prime} \mathrm{S}, 58^{\circ} 27^{\prime} \mathrm{W}\right.$; formerly Site of Special Scientific Interest no. 8) consists of a dryland on the western shore of Admiralty Bay, King George Island, the biggest island of South Shetland Islands, at about $120 \mathrm{~km}$ from the Antarctic Peninsula and about $900 \mathrm{~km}$ from Cape Horn (Figure 1). The mean annual air temperature is $-1.6^{\circ} \mathrm{C}$. The lowest temperature noted in the ASPA no. 128 area was of $-32.3^{\circ} \mathrm{C}$, and the highest one was of $+16.7^{\circ} \mathrm{C}$ (Marsz \& RakusaSuszczewski, 1987; Martianov \& Rakusa-Suszczewski, 1990). The mean temperature of the 5-cm surface layer of the soil is of $+4.0^{\circ} \mathrm{C}$ (in January) and $-1.8^{\circ} \mathrm{C}$ in September (Zwolska \& Rakusa-Suszczewski, 2002).

The soil is formed from basic volcanic rocks that were partly translocated by glaciers or solifluction of basic gneiss and volcanic ashes. The soil $\mathrm{pH}$ is moderately acid and decreases from surface to deeper horizons. Soils at the Admiralty Bay region are variable: Cambisols, Umbrisols, Regosols, Podzols, Leptosols, Gleysols and relic ornithogenic soils are found (Bölter et al., 1997). Soil is influenced by permafrost in the top $200 \mathrm{~cm}$. The dominant plant species on the oldest ice-free areas are Deschampsia antarctica and Colobanthus quitensis, as well as mosses (mainly Drepanocladus sp. and Polytrichum sp.). The newest ice-free areas have no plant cover.

Three transects were marked on ice-free areas between the Ecology, Baranowski and Windy Glaciers and the sea shore (Figure 2). In January 2008, soil samples $\left(120 \mathrm{~cm}^{3}\right.$ to
$5 \mathrm{~cm}$ depth each) were collected from 6,15 and 16 points from each of the transects. The samples were taken from the bare soil and from between the plant patches. The glaciers' retreat in 1956, 1979, 2001 and 2008 (i.e. 52, 29, 7 , and 1 years ago) was determined using the data available from maps (Pudełko, 2002, 2007). The transect points related to the areas where they were marked were assigned to four age classes: $0-7,7-29,29-52$ and $>52$ years of age (Table 1).

Samples were extracted using a modified high-gradient Macfadyen extractor (6 days, gradually from 20 to $35^{\circ} \mathrm{C}$ ) in a laboratory of the Henryk Arctowski Polish Antarctic Station near ASPA no. 128. The extracted mites were preserved in $70 \%$ ethanol and the specimens were determined (the oribatid mites to the species level). The data were analyzed by Kruskal-Wallis test and Mann-Whitney pairwise comparison using PAST version 1.83 (Hammer et al., 2001).

\section{Results and Discussion}

The mite abundance in each age class of the ice-free land was not significantly different $(\mathrm{p}=0.088 ; \mathrm{H}=6.357$; $\mathrm{Hc}=6.759)$. In pair-wise comparisons, differences

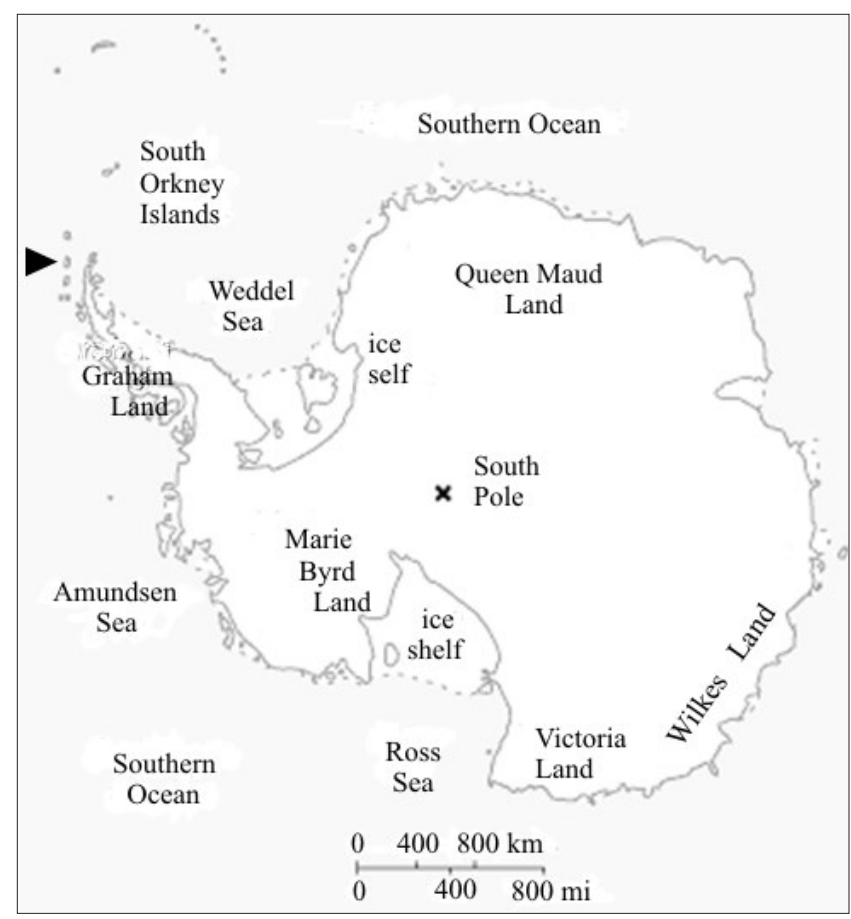

Figure 1. Localization of the King George Island (marked by the arrow) in Antarctica (Central Intelligence Agency, 2009; modified). 


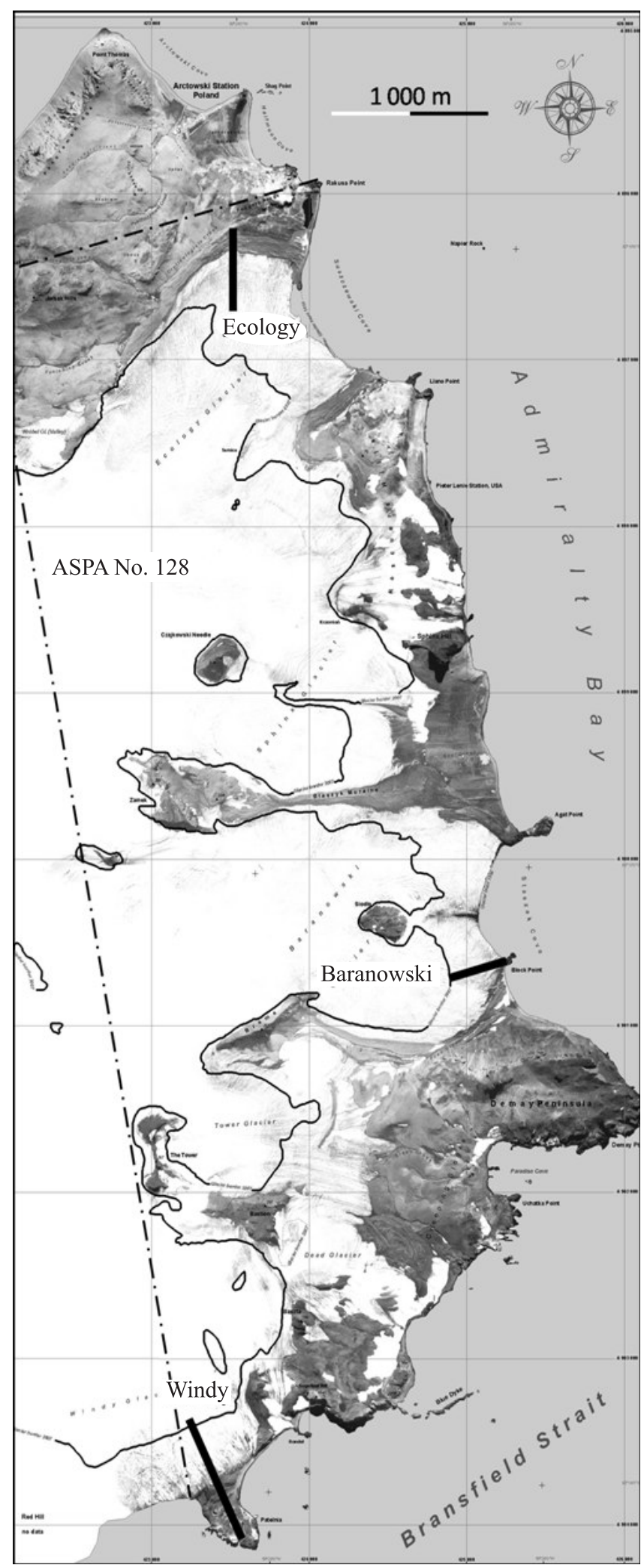

Figure 2. Ortophotomap (1979) of ASPA no. 128 with the location of the transects (-). The present (2007/2008) border of the glacier range is marked (Pudełko, 2007; modified).
( $p=0.016)$ occurred only between the age classes of $0-7$ years $(0.6$ individuals per sample; $\mathrm{SE}=0.4)$ and $>52$ years $(33.5 ; \mathrm{SE}=23.1)$. In the remaining age classes, the mean number of individuals per sample was of $2.6(\mathrm{SE}=0.7)$ for $7-29$ years and of $3(\mathrm{SE}=1.6)$ for 29-52 years (Figure 3). There were some trends in the data: the abundance of mites increased with the age of ice-free area ( $\mathrm{R}^{2}$ value: 0.896$)$. This is related to the development of vegetation cover on the ice-free land: the longer they were ice-free, the more vegetation they had. During the summer of 1990, Hiruta \& Ohyama (1995) reported $0-1$ mites per $100 \mathrm{~cm}^{3}$ (i.e. $0-1.2$ individuals per $120 \mathrm{~cm}^{3}$ ) on bare ground, $0-5$ $\left(0-6\right.$ in $\left.120 \mathrm{~cm}^{3}\right)$ on the moss community and $0-120$ $\left(0-144\right.$ in $\left.120 \mathrm{~cm}^{3}\right)$ on the lichen community in the

Table 1. Number of samples of each age class in each transect.

\begin{tabular}{lcccc}
\hline Transect & \multicolumn{4}{c}{ Age class (years) } \\
\cline { 2 - 5 } & $0-7$ & $7-29$ & $29-52$ & $>52$ \\
\hline Ecology & 1 & 2 & 0 & 3 \\
Baranowski & 0 & 8 & 4 & 3 \\
Windy & 4 & 2 & 1 & 9 \\
\hline Total & 5 & 12 & 5 & 15 \\
\hline
\end{tabular}

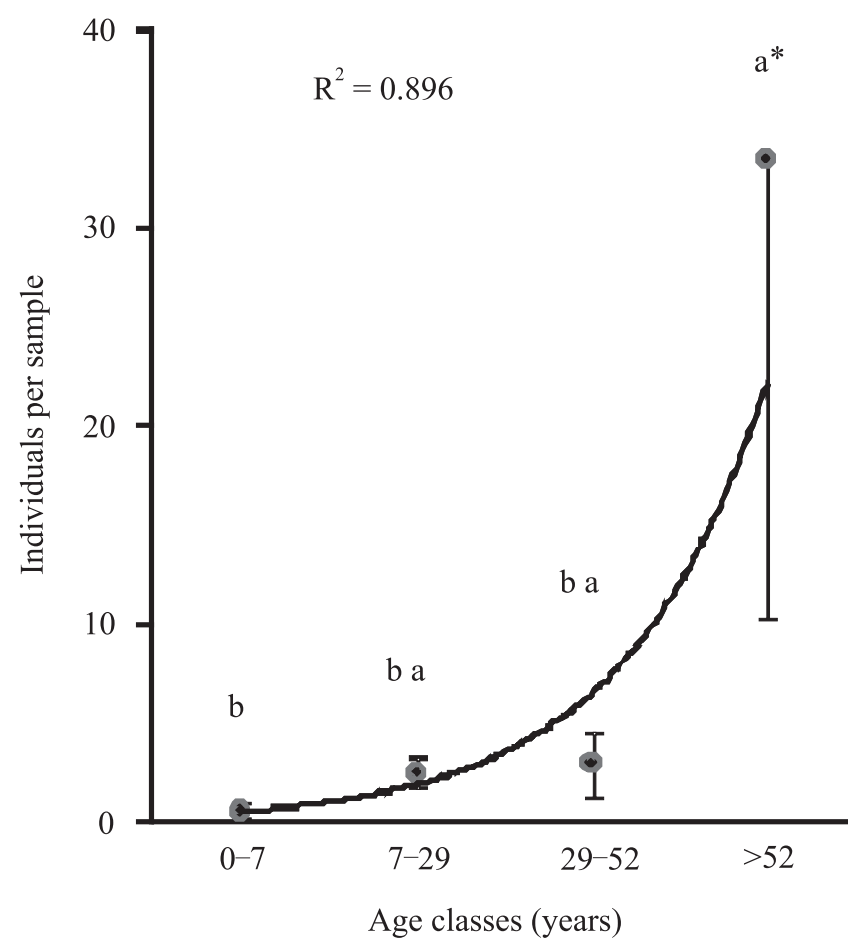

Figure 3. Density of mites at different age classes after ice retreat. SE and exponential trend curve are given; columns with identical letters are not significantly different from each other. 
inland nunataks of Sør Rondane Mountains (Dronning Maud Land, Antarctica).

Only three orders of mites were found in the present study: Prostigmata, Mesostigmata and Oribatida. The predominant order in all age classes was Prostigmata. At least $81 \%$ of the specimens belonged to this order (up to $100 \%$ in the $0-7$ years class) (Figure 4). No statistical differences in proportion of density of mite orders were detected between age classes. Two species of oribatid mites (Oppia sp. and Alaskozetes antarcticus) were found in the 29-52 and $>52$ years classes, on near-shore areas. There were no oribatid mites in the other age classes. Thus, oribatid mites were found only in the oldest ice-free areas, where the plant cover was well developed.

The soils in the $0-7$ and $>52$ years age classes differ from each other: in 0-7 years, there were Regosols and Gleysols only; in $>52$ years, there were Cambisols, Umbrisols and Podzols only. All mentioned soil types occurred in the remaining classes. Bölter et al. (1997) also noted the highest abundances of terrestrial arthropods in Cambisols, Umbrisols and Podzols. Initial types of soils (i.e. Regosols and Gleysols) seem to be adequate habitats for the colonization by Prostigmata only.

In an experiment on long-term development of oribatid communities during grassland succession following the conversion of arable fields, which was carried out under European temperate-climate conditions, the abundance of oribatid mites increased markedly after the conversion from arable land to grassland and reached its saturation at 29-40 years, with abundances of about $20 \times 10^{3}$ individuals $\mathrm{m}^{-2}$ (Zaitsev et al., 2006). The colonization of mill dumps by oribatid mites is much faster: they reach densities of $12 \times 10^{3}$ individuals $\mathrm{m}^{-2}$ after a couple of years and become the predominant group among mites after 10-15 years (Skubała, 2004). These results are 12-23 years faster than the ones found in the present study in Antarctica. However, there are notable differences

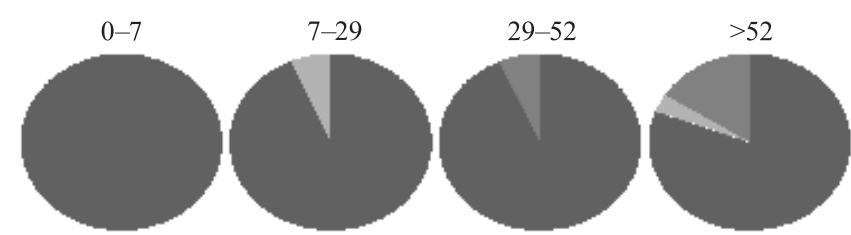

Figure 4. Proportions of Acari orders at each age class after glacier retreat ( $\square$ Prostigmata, $\square$ Mesostigmata, $\square$ Oribatida). between temperate latitudes and maritime Antarctica, which influence the rate of colonization, such as pedogenesis patterns (e.g. climate, plants, hydrological conditions) and number of species of mites with ability to colonize new, unpleasant areas. A better knowledge of rate and patterns of colonization by mites in ice-free areas is necessary to understand the effects of potential habitat changes as a result of global change.

\section{Conclusions}

1. The colonization by mite communities in maritime Antarctica is strongly determined by the vegetation cover.

2. In maritime Antarctica, Prostigmata are primary colonizers and they continue as the dominant group for decades.

3. In Antarctic conditions, oribatid mites colonize only areas where glaciers retreated at least 30 years before.

\section{Acknowledgements}

To the fellow members of the $32^{\text {nd }}$ Polish Antarctic Expedition, for providing deep scientific atmosphere.

\section{References}

BIRKENMAJER, K. Retreat of Ecology Glacier, Admiralty Bay, King George Island (South Shetland Islands, West Antarctica), 1956-2001. Bulletin of the Polish Academy of Sciences, Earth Sciences, v.50, p.15-29, 2002.

BOKHORST, S.; HUISKES, A.; CONVEY, P.; VAN BODEGOM, P.M.; AERTS, R. Climate change effects on soil arthropod communities from the Falkland Islands and the Maritime Antarctic. Soil Biology \& Biochemistry, v.40, p.1547-1556, 2008.

BÖLTER, M.; BLUME, H.P.; SCHNEIDER, D.; BEYER, L. Soil properties and distributions of invertebrates and bacteria from King George Island (Arctowski Station), maritime Antarctic. Polar Biology, v.18, p.295-304, 1997.

CARUSO, T.; BARGAGLI, R. Assessing abundance and diversity patterns of soil microarthropod assemblages in northern Victoria Land (Antarctica). Polar Biology, v.30, p.895-902, 2007.

CENTRAL INTELLIGENCE AGENCY. The world factbook: Antarctica. Available at: $<$ https://www.cia.gov/library/publications/ the-world-factbook/maps/maptemplate_AY.html>. Accessed on: 16 June 2009.

GATES, D.M. Climate change and its biological consequences. Sunderland: Sinauer Associates, 1993. 280p.

HAMMER, Ø.; HARPER, D.A.T.; RYAN, P.D. PAST: paleontological statistics software package for education and data analysis. Palaeontologia Electronica, v.4, p.9, 2001. 
HIRUTA, S.I.; OHYAMA, Y. A preliminary report on terrestrial invertebrates in the Asuka Station area, Antarctica. Proceedings of the NIPR Symposium on Polar Biology, v.8, p.188-193, 1995.

HOGG, I.D.; WILLIAMS, D.D.; EADIE, J.M.; BUTT, S.A. The consequences of global warming for stream invertebrates: a field simulation. Journal of Thermal Biology, p.20, p.199-206, 1995.

HUGHES, L. Biological consequences of global warming: is the signal already apparent? Trends in Ecology \& Evolution, v.15, p.56-61, 2000.

MARSZ, A.; RAKUSA-SUSZCZEWSKI，S. Charakterystyka ekologiczna rejonu Zatoki Admiralicji (King George Island, South Shetlands Islands), 1. Klimat i obszary wolne od lodu. Kosmos, v.36, p.103-127, 1987.

MARTIANOV, V.; RAKUSA-SUSZCZEWSKI，S. Ten years of climate observations at the Arctowski and Bellingshausen Station (King George Island, South Shetlands, Antarctica). In: Global change regional research centres: scientific problems and conceptive development. Warsaw: Institute of Geography and Spatial Organization, 1990. p.80-87.

NIEDBAŁA, W. Mechowce - roztocze ekosystemów lądowych. Warsaw: Państwowe Wydawnictwo Naukowe, 1980. 255p.

OERLEMANS, J. Glaciers as indicators of a carbon dioxide warming. Nature, v.320, p.607-609, 1986.

PUDEŁKO, R. Site of special scientific interest no. 8 (SSSI 8), King George Island, topographic map, 1:12 500 scale. Warsaw: Department of Antarctic Biology, 2002.
PUDEŁKO, R. Western shore of Admiralty Bay, orthophotomap, 1:10 000 scale. Warsaw: Department of Antarctic Biology, 2007.

PUGH, P.J.A.; CONVEY, P. Scotia Arc Acari: antiquity and origin. Zoological Journal of the Linnean Society, v.130, p.309-328, 2000.

SINCLAIR, B.J. On the distribution of terrestrial invertebrates at Cape Bird, Ross Island, Antarctica. Polar Biology, v.24, p.394-400, 2001.

SINCLAIR, B.J.; SJURSEN, H. Terrestrial invertebrate abundance across a habitat transect in Keble Valley, Ross Island, Antarctica. Pedobiologia, v.45, p.134-145, 2001

SKUBAŁA, P. Colonization and development of oribatid mite communities (Acari: Oribatida) on post-industrial dumps. Katowice: Wydawnictwo Uniwersytetu Śląskiego, 2004. 208p.

SMITH, R.I.L. Colonization by lichens and the development of lichen-dominated communities in the maritime Antarctic. Lichenologist, v.27, p.473-483, 1995.

ZAITSEV, A.S; WOLTERS, V.; WALDHARDT, R.; DAUBER, J. Long-term succession of oribatid mites after conversion of croplands to grasslands. Applied Soil Ecology, v.34, p.230-239, 2006.

ZWOLSKA, I.; RAKUSA-SUSZCZEWSKI, S. Temperature as an environmental factor in the Arctowski Station area (King George Island, South Shetlands Islands). Global Change, v.9, p.51-65, 2002.

Received on September 29, 2008 and accepted on July 8, 2009 